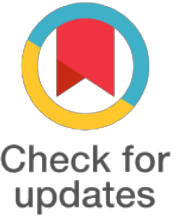

updates
${ }^{*}$ For correspondence:

dttloan@hcmus.edu.vn

Competing interests: The authors declare that no competing interests exist.

Received: 2017-08-05

Accepted: 2017-08-17

Published: 2017-09-05

Copyright The Author(s) 2017. This article is published with open access by BioMedPress (BMP).

This article is distributed under the terms of the Creative Commons Attribution License (CC-BY 4.0) which permits any use, distribution, and reproduction in any medium, provided the original author(s) and the source are credited.

\section{Increasing dose of intravenous human adipose-derived stem cells improves the pancreatic function of diabetic mice}

POSTER

\author{
Loan Thi Tung Dang, Anh Nguyen Tu Bui, Cong Le Thanh Nguyen, Nhat \\ Chau Truong, Anh Thi Van Bui, Ngoc Phan Kim, Kiet Dinh Truong, Phuc \\ Van Pham
}

Laboratory of Stem cell Research and Application, B2-3 Linh Trung Campus, University of Science, VNUHCMC, Ho Chi Minh, Ho Chi Minh o88, Vietnam

\section{Abstract}

Mesenchymal tem cell transplantation is a novel treatment for diabetes mellitus, especially type 1 diabetes. Many publications have proved the effect of MSC therapy on reducing blood glucose and improving insulin production in type 1 diabetic animal as well as in clinic trials. However, there is no conclusion that how many cells are effective for diabetes. Thus, this study has investigated that different adipose-derived MSC doses affected glucose metabolism in diabetic mice. STZinduced diabetic mice were intravenous transfused with human MSCs with dose either 106 (treated group A) or $2 \times 106$ cells/mouse (treated group B). Both treated and untreated mice were monitored the blood glucose levels, glucose and insulin tolerance test, pancreatic structure change and insulin production every week until 56 days after transplantation. The results showed that the higher dose of MSC could reduce death rate ( $66 \%$ vs. $0 \%$ death in group A vs. group B after 56 days of treatment, respectively) and remarkably lower blood glucose levels while the mice treated with $1 \times 106$ cells/dose remaining hyperglycemia. Moreover, the glucose tolerance and insulin tolerance as well as insulin production were improved in group B at 28 days after transplantation. The histochemical imaging further demonstrated the decrease of inflammatory cells in the islets and the restoration of pancreatic structures in higher-dose-MSCs-treated mice. Thus, the dose $2 \times 106$ cells of MSCs may be an effective strategy for diabetes mellitus concerning hyperglycemia, impaired glucose metabolism and islet destruction

\section{Keywords}

Diabetes, streptozotocin, dose, stem cell

\section{Funding}

This research was funded by Ministry of Science and Technology via project Grant No.

DTDL.2012-G/23 


\section{References}

1. Ezquer, F. E., et al. (2008). "Systemic administration of multipotent mesenchymal stromal cells reverts hyperglycemia and prevents nephropathy in type 1 diabetic mice." Biol Blood Marrow Transplant 14(6): 631-640.

2. Gao, F., et al. (2016). "Mesenchymal stem cells and immunomodulation: current status and future prospects." Cell Death Dis 7: e2062.

3. Kono, T. M., et al. (2014). "Human adipose-derived stromal/stem cells protect against STZinduced hyperglycemia: analysis of hASC-derived paracrine effectors." Stem Cells 32(7): 18311842 . 